\title{
HISTÓRIA NO DRAMA OU COMO DRAMA? INDAGAÇÕES SOBRE O DRAMA HISTÓRICO ALEMÃO
}

\author{
João Alfredo Dal Bello*
}

A

o se enfocarem as relações entre a literatura e a história, chega o momento do ajuste das lentes em direção ao assim chamado drama histórico. Desde logo instala-se a indagação do que constitui um drama histórico, questão sempre recorrente nos estudos da ciência literária. Lidamos aqui com um conceito problemático e paradoxal a partir da própria denominação do objeto de estudo, já que o drama pretende ser histórico, ou seja, serve-se do que aconteceu e foi, de alguma maneira, registrado, mas é gênero literário e, como tal, produto ficcional. Importa, portanto, refletir sobre a constituição desse tipo de construto. $O$ que se nos apresenta concretamente é uma produção que engendra personagens, datas, épocas, momentos, ações e acontecimentos do registro histórico, manuseados, contudo, pela liberdade criativa do escritor. Teríamos, então, de buscar uma definição que não se permitisse a superficialidade, porquanto deverá dar conta de uma vasta paleta dessas construções que, no contexto alemão, têm trazido aos palcos, ao longo do tempo, uma verdadeira avalanche de figuras históricas que antecedem Nero e vão além de Hitler. A necessária reflexão sobre a poética do drama histórico situa-se, portanto, no complexo campo de tensão entre historiografia e ficção.

* Universidade Federal do Paraná. 
Começando pelo começo, podemos indagar o porquê do drama histórico. Walter Hinck exerce reflexão a este respeito e diz: "Enquanto existir uma consciência histórica, haverá o desejo de, via representação, ir buscar acontecimentos significativos do passado, de vivenciá-los como algo atual: o conhecimento histórico deseja (novamente) tornar-se visível".1 (Hinck, 1981, p. 7)

Para o pensador, o drama histórico vem à luz por força da necessidade criada pela consciência histórica que temos de, via representação, vivenciar, no presente, acontecimentos históricos do passado. Isto implica pensar numa dupla historicidade, a do momento presente e aquela do momento referido. No romance Eumeswil (1977), de Ernst Jünger, publicado em português com o mesmo título, o narrador, um professor de história, sabe como suprir essa necessidade: ele tem um aparelho, espécie de computador, que dispõe de informações enciclopédicas sobre a história e é capaz de ultrapassar o tempo, trazendo ao presente pessoas e acontecimentos. Essa "máquina do tempo" revisita o passado e consegue trazê-lo ao espaço atual, promovendo um SchauSpiel da história. Além de materializar a história real, também o aparelho, chamado luminar, age com a história potencial: o que poderia ter sido, a utopia, o que não vingou, realiza-se agora concretamente. Em outras palavras, realiza-se uma historiografia inconsciente: o que não foi, poderia ter sido. $O$ invento, reunindo características de computador, teatro e cinema, é tão sofisticado que vai além destas possibilidades, por inserir quem o manuseia no fenômeno histórico. Como participante direto do acontecimento, o usuário pode ora estar em Berlim, "um pouco antes da morte de Hegel" e andar por ela "uns vinte anos [...] exatamente até a revolução do ano de 1848 do calendário cristão", ora na Revolução Francesa, assumindo, inclusive, papéis de personagens de então, quer dizer, não só lhe é facultado observar a história como também co-agir nela. Assim:

O luminar reproduz as imagens em toda a sua dimensão espacial; posso escolher, conforme queira, entre sentar-me na Montanha ou na Gironda, ocupar o lugar de presidente ou de porteiro, que talvez fosse quem melhor dominava a situação. Sou ao mesmo tempo acusador, defensor e acusado, completamente à vontade.

1 Solange ubberhaut ein GeschichtsbewuBtsein existiert, gibt es das Verlangen, bedeutende Ereignisse der Vergangenheit durch die Vorstellung zurückzuholen, já, sie wie etwas Gegenwärtiges zu erleben: historisches Wissen möchte (wieder) Anschauung werden (Hinck, 1981, p. 7). 
[...] o importante era compreender o sentido histórico que se ocultava no fundo das opiniões e dos acontecimentos (Jünger, 1987, p. 369-398).

Este salto aleatório ao passado, como se fora realidade virtual, recortando-o em forma de ficção, decorre da capacidade seletiva de nossa lembrança, "conforme queira", e é explicado pelo historiador Moses I. Finley: "Não nos lembramos de um acontecimento passado - quer o procuremos conscientemente em nossa memória, quer nos lembremos espontaneamente dele - abrindo nosso caminho do presente até o passado. A memória salta instantaneamente para o ponto desejado e então estabelece a data por associação." (Finley, 1989, p. 16).

Estas duas citações nos dizem que, numa situação como a dada, concorrem três elementos: o passado, caracterizado como registro documental, a memória, que o fixou, e a imaginação do escritor ou leitor no presente, que resgata os dois primeiros com toda a liberdade imaginativa de que dispõc. Isto parece encontrar respaldo no que Gaston Bachelard ensina a respeito da memória individual:

Em sua primitividade psíquica, Imaginação e Memória aparecem em um complexo indissolúvel. Analisamo-las mal quando as ligamos à percepção. $\mathrm{O}$ passado rememorado não é simplesmente um passado da percepção. [...] A imaginação matiza desde a origem os quadros que gostará de rever. Para ir aos arquivos da memória, importa reencontrar, para além dos fatos, valores. [...] Para reviver os valores do passado, é preciso sonhar, aceitar essa grande dilatação psíquica que é o devaneio, na paz de um grande repouso. Então a Memória e a Imaginação rivalizam para nos devolver as imagens que se ligam à nossa vida (Bachelard, 1988, p. 99).

Não seria, então, o luminar de Eumeswil o catalisador de todos esses elementos. Não seria a memória do registro documental revisitada pela imaginação do escritor que lhes confere uma figuração no presente? Ora, ao propiciar a identificação interior do "viajante" com uma personagem espacial, o luminar cria uma ilusão cênica. Também a adoção do papel histórico tem característica de jogo cênico, uma vez que esta repetição da história se escusa do caráter de obrigatoriedade existencial do fato primeiro. Assim, a experiência histórica se torna uma experiência estética. Tendo em conta que o luminar é um instrumento 
do historiador, evidencia-se a interpenetração dos dois fazeres. Dado emaranharem-se no drama histórico interesses estéticos e históricos, o luminar seria uma evocação da Geschichte als Schauspiel, ou seja, da história como representação lúdica, no sentido que lhe conferem o inglês e o francês, ao designarem a encenação como play e jeu. Para situar a reflexão teórica sobre o drama histórico ouçamos a voz de alguns estudiosos do assunto. Encontro grande valia na abordagem de Axel Schalk (1989), por descobrir nela um enfoque que me pareceu sistemático e econômico no tratamento da questão. Outras contribuições serão convocadas para aprofundá-la ou mostrar discordância interpretativa.

Schalk parte do pressuposto de que a indagação sobre o drama histórico é, na maioria das vezes, mal formulada e induz a constatações dogmáticas que refletem impropriamente a moderna relação entre literatura e história, por estabelecer a priori, como sustentáculo da aproximação, a verdade histórica. Essa linha fixa, categórica mas imprecisamente, se um drama histórico é falso ou verdadeiro. Convém, portanto, agrupar os representantes mais significativos desta convicção.

Friedrich Sengle (1969) orienta sua visão do drama histórico alemão pelo viés do desenvolvimento do pensamento histórico na segunda metade do século dezoito. Para ele, o desabrochar da composição literária apoiada na história tem sua origem na emancipação da burguesia alemã, embasada num anseio por pátria e liberdade. Assim, interpretando Götz von Berlichingen de Goethe, sustenta que é a partir desta obra que surge o autêntico drama histórico na Alemanha. Tal asseveração é, a um tempo, correta e problemática. É correta se considerados os aspectos da autonomia e da unicidade do acontecimento histórico, porquanto o palco da Idade Média vinculava a história à história sagrada do cristianismo, e dramaturgos como Hans Sachs ou barrocos comprimiam o mundo histórico em apertados moldes didáticos, apenas com uma função de referência, a serviço da religião ou dos costumes.

Problemático, na tese de Sengle, é que o autor vê na peça teatral histórica a partir de Götz uma reconstrução daquilo que efetivamente ocorreu. O drama de Goethe passa, nessa visão, a revestir-se do caráter de autêntica aula de história com inquestionável conteúdo de verdade, como se o gênio das letras alemãs tivesse o poder divinatório de conhecer a verdade histórica. É escusado dizer a parca utilidade de tal enfoque, já que avalia decadente a literatura histórica privada de "verdade interna"; vale, contudo, sua tentativa de descrever um tipo de produção literária em que se encontram personagens conhecidas de fontes do registro histórico agindo numa ação dramática. 
Concordam nesse entendimento Schalk e Hinck, e este acrescenta: “Mas o percurso do drama histórico de Götz a Galileu, e além disso, ensina algo diferente. A dramática histórica de boa qualidade será sempre representação do exemplar [...], sempre o autor modelará a matéria histórica de acordo com determinações prévias de sentido, nas quais o histórico encontrará as fronteiras de sua autonomia"2 (Hinck, 1981, p. 10).

Benno von Wiese, em estudos da década de 40 , percorre caminho idêntico ao de Sengle, quando destaca "autêntica" composição de "uso tendencioso" da história.

Von Wiese entende que o pomo da discórdia situa-se na difusa linha divisória entre as tarefas do historiador e as do literato. Por não se estabelecer o que a um e a outro compete, de ambos os lados "a grita se levanta ao céu da gente": querem uns uma imediata separação entre o que é inventado e o que é averiguado de forma confiável pela história, contestam outros que uma tal separação destruiria a unidade da obra artística; lamentam uns que essa composição literária exagera ou na imaginação ou na história, outros que ela se esquiva de ambas; uns criticam os anacronismos, outros os defendem; proclamam alguns o ficcionista histórico como senhor, enquanto os oposicionistas o chamam de servo, quando não de violador da história. Diante de tantos argumentos e contra-argumentos, von Wiese traz à memória a anedota do juiz de paz de Milão, que, ao dar razão às duas partes querelantes, é interpretado por seu filho, presente ao julgamento, sobre a impossibilidade de ambas terem razão. A resposta do juiz ao menino é que este também tinha razão. $O$ que, inicialmente, parece ser introdução a uma proposta conciliatória entre as partes envolvidas no que von Wiese chama de "historische Belletristik", é preâmbulo para algo como um anátema sobre a cabeça do literato que ouse invadir fronteiras da história a custos da "verdade".

Assim prevenido, o compositor de drama histórico deveria ter em mente que "a autêntica composição histórica será, portanto, uma interpretação da história [...] e que eleva o histórico a símbolo de uma verdade eterna [...]" (von Wiese, 1980, p. 385). Visto deste ângulo, somente o dramaturgo imbuído da ilibada consciência de um sumo-sacerdote poderia adentrar o lugar "santo dos

2 Der Weg des historischen Dramas vom Götz zu Brechts Galilei und darüber hinaus aber lehrt etwas anderes. Immer bleibt Geschichtsdramatik von Rang Darstellung des Exemplarischen [...], immer modelliert der Autor den geschichtlichen Stoff nach Sinn-Vorgaben, and denen das Geschichtliche die Grenzen seiner Autonomie erfährt (Hinck, 1981, p. 10). 
BELLO, J. A. Dal. História no drama ou como drama?

santos" com prévia autorização do deus-historiador. Merece a crítica de Francisco Moraes Paz, em bela incursão pelo pensamento de Peter Gay:

O historiador dizia distanciar-se dos escritores ficcionais pelo compromisso com a verdade. Cabia-lhe, pois, descobrir um velho universo; ao escritor ficava assegurado o direito de inventar um novo universo, o da ficção. Revendo tais premissas, Gay também destaca o ceticismo generalizado sobre a "história objetiva". Toda percepção é uma interpretação; toda exposição é uma perseguição. A possibilidade maior do historiador, afirma, está em passar da objetividade para a compreensão e em reconhecer que história e poesia têm origem comum, a imaginação (Paz, 1993, p. 23).

Concede von Wiese que ao ficcionista não se pode impor regras a propósito de seu comprometimento com a tradição histórica, nem sobre o espaço de sua liberdade, mas admoesta que "O drama histórico permanecerá incompleto e questionável sempre que o engenho livre se vir desvinculado internamente do dado histórico, ou quando os fatos históricos não forem permeados por aquele processo de afeiçoamento do poeta voltado ao 'geral', à totalidade dos fenômenos." 3 (von Wiese, 1980, p. 392-393).

Não somente desta citação, mas também de muitos outros momentos, depreende-se que von Wiese parte da firme convicção de que o registro do acontecimento histórico é inquestionável. Vale dizer, a linguagem do historiador não é permeada pela tropologia da qual se originam discrepâncias interpretativas, e que o drama histórico, se quiser erguer-se à condição de "autêntico", terá de submeter-se à pedra de toque que determinará a autenticidade da composição dramatúrgica calcada na vertente histórica. Será o Symbolbegriff (conceito-símbolo). Por este critério, poder-se-ia apurar até que ponto o ficcionista do drama histórico se torna um (Einswerdung) com a matéria histórica. Em decorrência,

3 Das Geschichtsdrama bleibt überall dort unvollkommen und fragwürdig, wo das frei Erfundene innerlich unverbunden neben dem geschichtlich Gegebenen steht oder die geschichtlichen Tatsachen nicht von jenem auf das "Allgemeine", auf die Totalität der Erscheinungen gerichteten Gestaltungsvorgang des Dichters durchdrungen sind. (von Wiese. 1980, p. 392-393). 
Será falso o drama histórico sempre que o eu se fantasiar de matéria histórica ou utilizá-la para enfeitar-se com penas artificiais que servem apenas para esconder a própria nudez. Tais formas de dramas históricos são pura e simplesmente uma mascarada, em que se substitui a verdade interna por fantasia externa, o caráter concebido pelo poeta por uma máscara, as forças atuantes no histórico por ornamentos acessórios e de efeito ${ }^{4}$ (von Wiese, 1980, p. 393).

Contrapõe-se à preceptoria de von Wiese a observação de Hayden White, ao estudar a postura de Humboldt em relação ao "tipo de entendimento que o historiador tem da realidade" e que não é o mesmo "reivindicado pelo artista romântico. Para o último, trata-se de um conhecimento puramente subjetivo, ou expressão de um estado emocional subjetivo"; para aquele, o que interessa é "uma apreensão do mundo que poderia ter existido no interior dos acontecimentos que aparecem no registro histórico". Quanto à verdade histórica, diz Humboldt que ela é "de maneira geral, muito mais ameaçada pela manipulação filosófica do que pela manipulação artística” (apud White, 1992, p. 192-193). $\mathrm{O}$ pensamento de Humboldt manifesta uma serena aproximação dos dois estudos, o que, na obra de Hayden White, encontra posição mais radical, ou seja, a abolição de distinção formal entre a narrativa histórica e a ficcional. Para ele ambas são construções verbais; o que as distingue é que a primeira se constrói sobre fatos reais e a outra sobre imaginários.

Também Ulrich Weisstein, no estudo de Schalk, articula seu posicionamento frente ao drama histórico sobre um sistema de categorias calcado no que é "certo" ou "errado". Segundo Schalk, Weisstein classifica o teatro documentário de Rolf Hochhut ou de Peter Weiss, por exemplo, como drama histórico do mais puro cunho, por ver neles isenção de uma simpática aproximação realista e de certo misticismo anti-histórico, protótipo do romantismo, coisas que abomina por induzirem ao drama histórico fascista. Para exorcizá-los vem o teatro documentário dos anos 60. Outra particularidade encontrada por Schalk

4 Unecht wird das Geschichtsdrama überall dort wo sich das Ich im geschichtlichen Stoff nur verkleidet oder ihn benutzt, sich mit künstlichen Federn zu schmücken, die die eigene BlöBe nur verdecken sollen. Solche Formen des Geschichtsdramas sind lediglich Maskerade, wo die innere Wahrheit durch das äuBere Kostüm, der vom Dichter geschaute Charakter durch die Larve, die im Geschichtlichen wirkenden Kräfte durch Staffage un Effekt ersetzt werden sollen (von Wiese, 1980, p. 393). 
nas dramatis personae de Weisstein é que sua determinação histórica supera a do indivíduo, tornando-se reprodução mimética do acontecimento histórico, a salvo de qualquer esfera privada, o que as eleva a protagonistas representantes do processo histórico, como quer o marxismo.

De fato, em estudo sobre as formas de realização do drama histórico, Weisstein explicita que importante e até decisivo para a qualificação de uma peça histórica não é tanto a envergadura do herói ou a transcendência política do tema, mas sobretudo a transposição de uma ação da esfera privada para a pública como reflexo de um sistema. Para respaldar este entendimento, Weisstein evoca a sexta cena de Mãe Coragem e seus filhos, de Brecht, em que a protagonista lembra que o destino dos descamisados é mais importante que o das grandes figuras. Ao ouvir, de longe, as salvas de canhão que acompanham o enterro do capitão Tilly, observa o capelão militar que esse é um momento histórico. Mãe Coragem prontamente contesta que para ela o momento é histórico por terem espancado sua filha.

Parece-me sobremodo estreita a qualificação proposta por Weisstein, por atrelar-se a um viés político partidário que tem a pretensão de prescrever ou decidir em nome de um critério absolutizante. Se o corriqueiro for desprezivel por ser afeto tão-só à esfera individual, prefiro pensar para o drama histórico o que Henri Lefebvre dizia da filosofia:

O cotidiano diz respeito a todo mundo. [...] A filosofia sempre excluiu a vida cotidiana: tradicionalmente era a vida nãofilosófica, trivial, sem sentido, da qual era preciso afastar-se para se elevar à meditação, para alcançar essa "noite clara da angústia" de que fala Heidegger. Minha proposta foi, pelo contrário, incluir a vida cotidiana na filosofia, fazer dela um objeto de meditação filosófica [...] uma maneira "não banal de ver a banalidade" (Lefebvre, 1989, p. 132).

Este pensamento remete às Teses de Walter Benjamin. Nelas se aprende: "o cronista que se põe a contar os acontecimentos, sem distinguir pequenos e grandes, presta tributo à verdade de que nada do que alguma vez tenha acontecido pode ser considerado perdido para a história" (Benjamin, 1985, p. 155).

E por ser mencionado o pensamento marxista dentro da questão do drama histórico, há que ser lembrado o nome de Georg Lukács e o de "seu escorregadio seguidor" (Posada, 1970, p. 198) Ernest Schumacher.

Lukács desenvolve, no segundo capítulo de sua obra, datada de 1936/37, $O$ romance histórico, um estudo paralelístico entre este e o drama histórico. Em 
nota preliminar à edição de 1954, o autor concorda que, do ponto de vista científico, seria mister uma revisão imposta por dezesseis anos decorridos desde o aparecimento da obra, sobretudo pelas falsas expectativas que evidenciava em relação ao movimento de libertação do povo alemão, o que "em nada muda o significado das questões teóricas levantadas e a direção a ser tomada na busca de sua solução" (Lukács, 1965, p. 18). Opta, assim, por oferecê-lo novamente em sua forma original, entendendo que a literatura produzida naquele ínterim não conseguiu ultrapassar as questões por ele levantadas inicialmente. Também o faz por ser seu objetivo de natureza teórica, e não o de historiar a literatura. Por isso alerta o leitor a não esperar do livro uma obra didática sobre o desenvolvimento do romance e do drama históricos; o alvo a que se propôs inicialmente, e reiterado agora, "é a investigação da reciprocidade entre o desenvolvimento econômico e o social e a visão de mundo e de forma artística daí decorrentes" (Lukács, 1965, p. 19).

Basicamente Lukács crê que se a arte contemporânea pretender dar conta, de modo crítico e humanista, da realidade atual, deve ligar-se organicamente às grandes tradições da literatura realista do passado. Assim, suas teorias teatrais seguem um desenvolvimento e aplicação dos critérios clássicos, bem sistematizados na Estética de Hegel.

Para o filósofo húngaro, o drama se define como conflito que simplifica e generaliza as possiveis atitudes dos homens diante de seus problemas vitais. Cabe ao dramaturgo, se quiser construir com sucesso a figura do herói, configurá-lo como catalisador das tensões sociais, morais e psicológicas do ser humano e apresentá-lo como Demonstrationsmodell. Nesse entendimento, será o drama verdadeiro quando a figura dramática fundir-se tanto quanto possível com o "ser histórico da colisão". O processo histórico se identifica com o processo de ação da personagem; há uma concatenação simbiótica entre indivíduo e colisão histórica concreta. É assim que o estudioso interpreta Kabale und Liebe de Schiller, por ver na peça o somatório do social, histórico e humano (Lukács, 1965, p. 143).

Rastreando ainda o ponto de vista de Goethe, Puschkin e Belinskij, Lukács conclui que todos eles têm em comum o endosso da fidelidade do autor à fiel reprodução das grandes colisões, das grandes crises e momentos de transição da história. Para expressar de forma adequada essa apreensão histórica, o escritor pode manejar livremente os fatos avulsos, uma vez que estes não comprometem a verdade histórica intrínseca. Nesse direcionamento, decisiva será a relação do escritor com a história: não poderá ser isolada, mas terá de estar em consonância com a realidade total e sobretudo com a sociedade. Assim, o reconhecimento lúcido do passado depende de uma lúcida avaliação 
do presente, ou, de trás para frente, o passado é entendido como pré-história do presente.

Em estudo construído sobre três pilares (materialismo histórico e drama histórico; a Revolução de Outubro e o drama histórico, e verdade histórica e verdade poética), Ernst Schumacher (1980) sustenta não haver para o dramaturgo histórico objeto mais adequado que a revolução, na qual a própria história assume traços dramáticos. $\mathrm{O}$ dramaturgo, em seu entender, "não precisa acrescentar nada, apenas deve visualizar o ser intrínseco dos acontecimentos. A revolução contém os elementos dramáticos da história" (Schumacher, 1980, p. 405). Nela se encontra o que é típico do passado, aquilo que é geral, assim como o que é típico do futuro, o novo e o especial. Para o pensador marxista, a história já carrega em si uma constituição dramática objetiva, basta que se lhe conceda, pela via dramatúrgica, a oportunidade de demonstrar o processo revolucionário para que atinja sua compleição. Em consequiência, o drama histórico materialista não tem objetivo em si mesmo; sua função é a de visualizar a história passada para o homem de hoje. E, nesta proposta, Schumacher se apóia em Brecht, e este em Marx, quando diz que o dramaturgo marxista não está tão preocupado em interpretar o mundo quanto em transformá-lo. Fica evidente que o drama histórico materialista só preencherá o espaço que lhe é reservado se abarcar as forças encontradas na representação com aquelas que enfoca e visa na atualidade, em forma de analogia. Não devem mais pairar dúvidas de que para Schumacher o drama histórico está posto a serviço das pretensões marxistas, o que traduz: não existe automatismo histórico; a história é feita pelos homens. $\mathrm{O}$ indivíduo, naquela linha de pensamento, torna-se ipso facto personalidade histórica, ele se torna representante de uma classe: como indivíduo não poderá mudar os rumos da história, mas pode agir como executor de mudanças, em nome da mesma classe. Significa dizer que a classe se apresenta como personalidade histórica na história. Se houver um herói como sujeito histórico, este será a massa. Assim, a ação da massa é primordial; a do indivíduo, secundária.

No espaço seguinte de seu estudo, Schumacher lança um olhar retrospectivo sobre o drama histórico e constata que Büchner, pela primeira vez, o abordou de maneira genial, ao mostrar que Danton, na peça evocativa da Revolução Francesa, fracassou por estar em contradição com a massa. Confere ao dramaturgo o mérito de, nessa peça, conceder à história o espaço que se lhe devia, pelo fato de, ao lado de personalidades históricas, comparecer a massa. O indivíduo com características de herói será representante de seu coletivo e agirá como protagonista social. Nessa linha de pensamento, fica evidente uma concepção de história, em que a figura do herói é construção do historiador. $\mathrm{Na}$ 
retrospectiva sobre o drama histórico, também o naturalista Gerhart Hauptmann, por sua peça Die Weber, deve, pela arbitragem de Schumacher, subir ao podium, contudo em segundo lugar, e justifica, fiel à sua profissão de fé marxista: “O Naturalismo alemão ficou sobremodo preso ao positivismo da Ciência Natural para que pudesse aplicar o materialismo histórico à sua teoria estética e à sua prática artística."5 (Schumacher, 1980, p. 412-413).

No mesmo estudo, Schumacher abre espaço para a indagação sobre a beleza que a uma obra de arte se atribui como característica imanente. Deixa de lado, por considerar pouco oportuno ao trabalho, o questionamento da "beleza natural objetiva", uma vez que, em se tratando de drama histórico, o que se oferece como objeto de enfoque é a vida em sociedade. Cabe, portanto, evidenciar o belo na interação humana, que é o próprio exercício da história. E esta beleza revela-se objetivamente sempre que vier a demonstrar o esforço do homem para a conquista de sua plena realização como tal, ou seja, no processo do trabalho que de escravo da natureza o torna senhor, que de oprimido e explorado passa a ser livre e igual. Alcançando o drama histórico a demonstração e visualização dessa luta, terá alcançado também o reflexo em si da beleza objetiva e o próprio drama reveste-se da qualidade de beleza pela adoção da práxis social. Contudo, essa beleza somente adquirirá perfeita compleição quando aliada a um produto artístico condizente. No conceito de Schumacher, a beleza do drama histórico será tão maior, quanto mais clara e evidente se tornar a verdade histórica.

Tarefa do dramaturgo histórico será, portanto, manusear o instrumental poético de tal forma que reproduza a poesia da história. "Somente desta forma ele também poderá ser poeticamente verdadeiro." (Schumacher, 1980, p. 419).

Tão determinante é a solidez da verdade histórica para Schumacher, que dela dependerá a beleza do drama.

O pensamento de Schumacher, a propósito do drama histórico, evidencia ortodoxia tal que só autoriza a levar essa denominação à produção avalizada pela concepção marxista-leninista de história e de teatro.

A leitura da argumentação marxista estabelece uma linha política matizada de estética, porquanto o atrelamento do drama à verdade histórica não é senão domesticação de pressupostos estéticos da peça e ajoujo a uma determi-

5 Der deutsche Naturalismus blieb zu sehr im naturwissenschaftlichen Positivismus befangen, um den historischen Materialism für seine ästhetische Theorie und seine künstlerische Praxis anwenden zu können (Schumacher, 1980, p. 412-413). 
nada e rígida concepção da história. Uma argumentação dessa natureza postula racionalidade absoluta em relação ao produto estético e extingue, em última instância, a existência histórica própria deste.

Torna-se, portanto, complicado acatar uma ordenação de pensamento, seja ela orientada pelo marxismo ou não, quando prega a ficção do drama histórico sofreada por um conceito irracional de verdade da história. Creio que, neste campo, pode ser aplicado, por analogia, o rigoroso julgamento de Freud, aqui citado por Donald A. Prater, a propósito da escritura de biografias: “Quem se torna biógrafo compromete-se com a mentira, a ocultação, a hipocrisia, o enfeite e disfarce e até com a dissimulação de sua insensatez, porquanto não se pode alcançar a verdade biográfica, e ainda que isso fosse possível, seria inútil.",6 (Prater, 1982, p. 10).

Entendo que composição ficcional e história são duas diferentes mas solidárias interpretações da vida. Por isso, ao nos indagarmos das diferenças, dos graus de valores ou da utilidade de uma e outra para o ser humano, teremos de ouvir a admoestação de Goethe, trazida muito a propósito por Karl Viëtor (1980): “A indagação sobre quem é superior, o historiador ou o poeta nem deve ser feita; eles não concorrem entre si, tal como aquele que pratica a corrida e o que pratica queda de braço. A cada um os seus louros." Com muita modéstia, pretendo ir além do pensamento goetheano, dizendo que tal indagação nem pode ser feita porque se compararmos os dois fazeres, em relação ao objeto histórico, teremos de admitir que o objeto de enfoque do ficcionista não é o fenômeno histórico original, mas um relato dele, e o que ele engendra não traz em si pretensão de disciplina. Parece-me que o mergulho do ficcionista no relato histórico é a busca do protofenômeno humano, naturalmente inserido nos registros da humanidade, como se em cada ser humano residissem todas as formas e caracteres da humanidade. É por esta razão que ele, ao garimpar o passado de um, mas que é de todos, sente-se autorizado a executar uma leitura liberta de amarras. Entendo também que a querela que vem se arrastando até hoje sobre a verdade ou pureza da representação da história, sobre a objetividade ou as condições indispensáveis para que o historiador exerça seu mister de forma impoluta são fortes evidências de um anseio geral pela restauração ou, então, instauração do verdadeiro sentido da história.

6 Wer Biograph wird verpflichtet sich zur Lúge, zur Verheimlichung, Heuchelei, Schönfärberei und selbst zur Verhehlung seines Unverständnisses, denn die biographische Wahrheit ist nicht zu haben, und wenn man sie hätte, wäre sie nicht zu brauchen (Prater, 1982, p. 10). 
Isto posto, ouso questionar a validade da determinação conceitual drama histórico. Não fosse o problema de definição somado à abundância de peças teatrais que se apropriam da história, agrega-se ao complexo campo a busca de um gênero literário que encampe satisfatoriamente essa poética. Como conciliar, no sentido da ciência literária tradicional, inclinada a "une place pour chaque chose; chaque chose à sa place", uma heterogeneidade da literatura como a que se nos apresenta no século XX? Parece-me que a multiplicidade dos paradigmas do assim denominado drama histórico, os diferenciados enfoques que lhe dão os estudiosos, além das concepções de mundo e de história de quem opina sobre $o$ assunto, levam o interessado na matéria a um posicionamento que, se desapossado de avanço na elucidação do problema, terá o mérito de ser econômico na descrição: importa refletir tão-somente de que modo o material histórico será apropriado pela peça teatral.

Antes de intentar a apresentação mais embasada da proposta acima, é mister arrolar os motivos básicos que me levam à refutação de definições dogmáticas e absolutizantes da dramaturgia histórica:

- O debate sobre drama e escrita da história, encetado por Aristóteles, sublinhou até Lessing, no contexto alemão, a autonomia da obra de arte - aqui a dramaturgia - em relação à história. Isto quer dizer que não se pode pretender uma identidade de documento histórico com produto estético. Foi Lessing, no contexto alemão, quem abertamente desatou as mãos do poeta em relação às injunções do registro histórico. $O$ interessante estudo de Viëtor deixa evidente que, para Lessing, composição poética enfabulada historicamente não pode ter outra determinação além daquela própria da composição poética, ou seja, que o poeta não tem de se preocupar com a unicidade e singularidade histórica: ele mostra, no exemplo do caso isolado, a verdade universal, pois, partindo de Aristóteles, afirma Lessing: "No teatro não devemos aprender o que este ou aquele indivíduo fez, mas aquilo que cada pessoa com um certo caráter e sob certas circunstâncias faria."

O que Lessing nos quer ensinar é que a história se configura como um repositório de caracteres humanos a serem plasmados poeticamente pela força mitificadora da tradição e que a matéria histórica conta com a vantagem da credibilidade, pois tudo o que já aconteceu é mais fidedigno do que o não

7 Auf dem Theater sollen wir nicht lernen, was dieser oder jener einzelne Mensch getan hat, sondern was ein jeder Mensch von einem gewissen Charakter unter gewissen gegebenen Umständen tun würde (apıd Viëtor, 1980, p. 371). 
BELLO, J. A. Dal. História no drama ou como drama?

acontecido. Entendido assim, a história pode oferecer-nos a verdade externa, a poética, a interna. $O$ poeta dramatúrgico deve mostrar que um ser humano pode, numa circunstância como a dada, sentir, comportar-se e expressar-se da forma como a que ele, poeta, concebe. Bem antes, como Viëtor mostra, também o jovem Schiller, na trajetória de Lessing, confessava sem dissimulação: "A História é apenas um arquivo para minha fantasia, e os objetos têm de aceitar o que minhas mãos fizerem deles" (Viëtor, 1980, p. 371).

- O pensamento dogmático deixa de lado o fato de que quem escreve é determinado historicamente, ou seja, que o dramaturgo é influenciado pela leitura e interpretação do registro histórico, efetuado por um relator também sujeito a influências. Em outras palavras, a recepção do relato histórico - que também não foi isento - influencia a poética dramática. Olvida o mesmo pensamento que esse tipo de dramaturgia não é apenas um documento histórico, testemunho concentrado de nossa consciência histórica, mas também é modelo de reconhecimento da história e reflexão sobre o seu relato, isto é, que a relação entre o presente e o passado, na qual nos inserimos, leva-nos a questioná-la.

- $O$ drama histórico tem sua trajetória própria. Esquecer-se disto equivale a anular o processo de uma tradição literária evidenciada como repositório da memória humana. Entendo o drama histórico como uma deslitação poética e humana do saber-se inserido na história e da vivência de uma atualidade explicada como fruto do que fomos. Assim sendo, por que não permitir-se uma viagem num luminar que nos permita, lembrando Walter Benjamin, uma leitura a contrapelo daquilo que nos foi legado como vivência pretérita?

Ainda permanece a pergunta: o que é um drama histórico? Temo que não haja resposta exata, e das insidiosas é mister precaver-se. Os passos seguintes devem levar-me a conformar uma posição.

Axel Schalk enriquece o debate trazendo dois autores que não só discordam do pensamento tradicional mas também apresentam um novo viés para a aproximação do drama à história. São eles Christoph Hein e Dieter Forte. Ambos partem da evidência de que atualmente há um avultado número de obras para o palco que recorrem aos registros históricos na sua enfabulação. Se, portanto, a atualidade se interessa pela história passada é pelo fato de esta ter uma significação hoje. Isto, conforme Hein, quer dizer que o presente é que está sendo tratado e o pregresso serve de "modelo de representação para alguns contemporâneos". Passado e presente estabelecem desta forma um relacionamento reflexivo-produtivo.

Dieter Forte argumenta de modo semelhante, ao abordar a questão da literatura histórica e seu significado em nossos dias: 
Por que peças históricas [...], e como são escritas? [...] Histórico? Em relação ao teatro não sei o que fazer com este conceito. Para o teatro ele não tem o significado que tem para a ciência. [...] História também era a matéria para "peças históricas" de autores históricos: as Guerras das Rosas de Shakespeare, A Guerra dos Trinta Anos de Schiller, a Revolução Francesa de Büchner [...]. Hoje encenadas, resultam em um triplo passado, o de Büchner em relação à Revolução Francesa, o nosso em relação a Büchner e à Revolução Francesa. E se com isso pretender-se, no teatro, algo no futuro, $[\ldots]$ haverá uma bela confusão de tempos. $[\ldots]$ Portanto, o conceito "peça histórica" não corresponde à realidade do teatro e de seus autores. Vamos deixá-lo de lado, ele não presta (apud Schalk, 1989, p. 16).

Forte deixa claro que lhe causa mal-estar a tentativa de se calcar à função comunicativa do teatro um conceito científico que se esgota, cenicamente, na discrepância das três camadas do passado: a do autor dramatúrgico em relação ao fato histórico, a do espectador em relação ao dramaturgo e ao fato histórico, e, se a obra apontar para o futuro, maior será a confusão. Melhor esquivar-se de tal conceito, e entender que um drama histórico é anacronista: mostra-nos, na encenação presente, como o passado poderia ter sido, isto é, como o hoje pode se expressar em relação ao ontem. Assim visto, não importa o modo como um crítico definirá a relação entre poética e história; ele sempre estará reconhecendo que as duas formas de escrita seguem suas próprias regras e convenções.

Depreendo que tanto Hein como Forte abolem a dicotomia drama histórico/drama da atualidade. Para ambos há peças atuais que evocam temas do passado, sem, contudo, impor-se o jugo de fidedignidade ao fato histórico. Este oferece, antes, um material teatral, como também Brecht aceita, que, pelo

8 Warum historische Stücke [...], und wie werden sie geschrieben? [...] Historisch? Ich kann mit dem Begriff, auf das Theater angewendet, nichts anfangen. Für das Theater hat er nicht die Bedeutung, die er in der Wissenschaft hat. [...] Geschichte war auch der Stoff für die "historischen Stücke" historischer Autoren: Shakespeares Rosenkriege, Schillers DreiBigjähriger Krieg, Büchners Französische Revolution [...]. Heute gespielt, ergibt sich eine dreifache Vergangenheit, die von Büchner zur Französischen Revolution, die von uns zu Büchner und zur Französischen Revolution. Ist damit dann auf dem Theater [...] Zukünftiges gemeint, [...] geraten die Zeiten ganz. schön durcheinander. [...] Der Begriff "historisches Stück" trifft also nicht die Realität des Theaers und seiner Autoren, legen wir ihn beiseite, er ist untauglich (apud Schalk, 1989, p. 16). 
manejo do autor, coloca passado e presente num relacionamento produtivo. A este respeito bem lembra Eloá Heise:

\begin{abstract}
Para o escritor de hoje não há mais limitações de gêneros ou campos estéticos; a obra se transforma em uma simbiose onde coexistem aspectos outrora irreconciliáveis: ciência e filosofia, mito e matemática, exatidão realista sem claro contexto, alternâncias de sujeito e objeto. Mesmo assim, o artista sente-se onipotentemente impotente e projeta a busca por seu tempo em direção a analogias do passado. A consciência de simultaneidade, comum ao homem moderno, fez com que nosso tempo perca seus próprios contornos e seja relativizado. Tentando desvendar a realidade que nos é própria, o poeta se apossa da tradição para reavivá-la e, ao mesmo tempo, pô-la em xeque, na medida em que a transgride. Assim, ele também the rende uma homenagem (Heise, 1989, p. ii-iii).
\end{abstract}

Creio ter mostrado as distintas acepções do assim chamado drama histórico, entre estudiosos alemães. Um grupo expressivo é configurado por pertinaz insistência na dicotomia verdadeiro-falso; o outro, diametralmente oposto, acata tão-somente que esse construto dramatúrgico apenas pode refletir o modo como se apropriou do material histórico.

Tomo posição ao lado de Forte e Hein também pelas seguintes razōes: -Quiséssemos estabelecer uma conceituação inatacável, teríamos de nos digladiar com a problemática definição e uma extensa lista de dramas considerados históricos, o que, provavelmente, resultaria, na melhor das hipóteses, em mais uma abordagem pulverizada e pouco econômica;

- A tentativa de apontar para uma tipologia de gênero, no sentido tradicional da ciência literária, encontraria forte oposição na heterogeneidade da literatura do século XX;

- Os multiformes paradigmas de drama histórico, os divergentes pontos de partida dos autores, somados às suas antipódicas visões de mundo e de história, parecem não indicar uma pesquisa calcada na tipologia de gêneros e de conceituação;

-Etiquetas de gêneros devem ser apenas indicadores que apontem para características salientes de um texto, orientando e estruturando a sua leitura. A individualidade de um texto nunca poderá ser inteiramente encampada e coberta por uma definição generalizante: sempre haverá apenas aproximações do específico ao geral. Ressaltar essas aproximações, entendendo que elas ofere- 
cem a possibilidade de acesso a um texto, pode ser suficiente para organizar a compreensão da forma e do conteúdo do mesmo texto e da expectativa do autor em relação a ele.

Assim entendido, proponho que a aproximação ao drama histórico seja pela via de associação a um conceito estabelecido, sem esperar dele mais do que pode oferecer: o tom, para falar com a linguagem da música. Nesse entendimento, teremos uma peça teatral constituída por um encontro de ficcionalidade e material factício em aproveitamento, a ser manipulado pelo dramaturgo, seja ele aristotélico, épico ou naturalista. Isto seria o que Brecht chama de Materialwert, ou seja, a funcionalização dramática da fonte histórica, excluído qualquer sistema que trabalhe com as categorias próprio/impróprio, autênticolfalso, privado/público.

\section{RESUMO}

Este trabalho investiga as distintas concepçōes de drama histórico, uma vertente fértil na dramaturgia alemã, contudo não isenta de controvertidas abordagens teóricas.

Palavras-chave: literatura e história, ficção e historiografia, drama histórico.

\section{ABSTRACT}

This paper deals with the different meanings of historical drama, a fertile, though controversial, element in German dramaturgy.

Key words: literature and history, fiction and historiography, historical drama.

\section{REFERÊNCIAS BIBLIOGRÁFICAS}

BACHELARD, Gaston. Os devaneios voltados para a infância. In: A poética do devaneio. Trad. por Antonio de Padua Danesi. São Paulo : Martins Fontes, 1988. 
BENJAMIN, Walter. Teses sobre a filosofia da História. In: KOTHE, Flávio (Org.). Walter Benjamin. São Paulo: Ática, 1985. p. 153-164.

FINLEY, Moses I. Mito, memória e história. In: Uso e abuso da história. Trad. por Marylene Pinto Machael. São Paulo: Martins Fontes, 1989.

HEISE, Eloá. Apresentação: a literatura como fonte da literatura. Cadernos da Semana de Literatura Alemã Contemporânea, n. 2. São Paulo: FFLCH-USP, 1989.

HINCK, Walter (Hrsg.). Geschichte als Schauspiel: Deutsche Geschichtsdramen. Frankfurt am Main: Suhrkamp, 1981.

JÜNGER, Ernst. Eumeswil. Trad. por Vera Mourão. Rio de Janeiro: Guanabara, 1987.

LEFEB VRE, Henri. Idéias contemporâneas. São Paulo: Ática, 1989. p. 131-137. Entrevistas do Le Monde. Entrevista.

LUKÁCS, Georg. Der historische Roman. Neuwied: Luchterhand, 1965 (Georg Lukács Werke, Bd. 6, Probleme des Realismus 3).

PAZ, Francisco Moraes. Sobre a história narrativa: (n)a promoção da escrita criativa. Letras, Santa Maria, n. 6, Centro de Artes e Letras da Universidade de Santa Maria, p. 7-26, jul./dez. 1993.

POSADA, Francisco. Lukács, Brecht e a situação atual do realismo socialista. Trad. por A. Veiga Fialho. Rio de Janeiro: Civilização Brasileira, 1970. (Col. Perspectivas do Homem, 67).

PRATER, Donald A. Stefan Zweig: Das Leben eines Ungeduldigen. Trad. por Annelie Hohenemser. München Wien: Carl Hanser Verlag, 1982.

SCHALK, Axel. Geschictsmaschinen: über den Umgang mit der Historie in der Dramatik des technischen Zeitalters. Heidelberg: Carl Winter Universitätsverlag, 1989.

SCHUMACHER, Ernst. Geschichte und Drama. In: NEUBUHR, Elfriede (Hrsg.). Geschichtsdrama. Darmstadt: Wissenschaftliche Buchgesellschaft, 1980. p. 404425.

SENGLE, Friedrich. Das historische Drama in Deutschland: Geschichte eines literarischen Mythos. Stuttgart: W. Kohlhammer, 1969.

VIËTOR, Karl. Dichter und Geschichte. In: NEUBUHR, Elfriede (Hrsg.). Geschichtsdrama. Darmstadt: Wissenschaftliche Buchgesellschaft, 1980. p. 361-380 (Wege der Forschung, Bd. 485).

WEISSTEIN, Ulrich. Das Geschichtsdrama: Formen seiner Verwirklichung. In: GRIMM, Reinhold; HERMAND, Jost (Hrsgs.). Geschichte im Gegenwartsdrama. Stuttgart: W. Kohlhammer, 1976. p. 9-23.

WHITE, Hayden. Meta-história: a imaginação histórica do século XIX. Trad. por José Laurêncio de Melo. São Paulo: Ed. da Universidade de São Paulo, 1992. (Col. Ponta, 4).

WIESE, Benno von. Geschichte und Drama. In: NEUBUHR, Elfriede (Hrsg.). Geschichtsdrama. Darmstadt: Wissenschaftliche Buchgesellschaft, 1980. p. 381-403 (Wege der Forschung, Bd. 485). 